\title{
Juridiske rammevilkår for etablering av helseregistre og utlevering av data i forbindelse med forskning
}

\author{
Ingunn Myklebust, jurist, seniorrådgiver \\ Avdeling for spesialisthelsetjenester, Sosial- og helsedirektoratet \\ Telefon: 24163186 Telefaks: 24163001 e-post: inm@shdir.no
}

\begin{abstract}
SAMMENDRAG
Før et forskningsprosjekt kan settes i gang, må forskere forholde seg til en rekke omfattende søknadsprosedyrer. I denne artikkelen belyses forhold som er spesielt aktuelle for forskere, slik som muligheter og begrensninger for innhenting av data til forskning og tilgjengelighet av data fra sentrale helseregistre. Som bakgrunn benyttes helseregisterloven og tilhørende forskrifter for de sentrale helseregistrene. Regler om dispensasjon fra taushetsplikt blir også nærmere belyst.
\end{abstract}

\section{Myklebust I. The legislative framework for establishing health registers and for obtaining access to data for research purposes. Nor J Epidemiol 2004; 14 (1): 13-16.}

\section{ENGLISH SUMMARY}

Before a research project can be initiated, researchers must relate to a series of comprehensive procedures for making an application. In this article, the conditions that are particularly relevant for researchers, such as the possibilities and restrictions for collecting data for research purposes, and for obtaining access to data from central health registers, are discussed. The Personal Health Data Filing System Act and related regulations are used as background for the discussion. The regulations relating to exemption from the duty of confidentiality are also discussed.

Mange vil påstå at muligheten til å drive forskning begrenses av regler som skal verne om personvernet. Helseregisterloven legger opp til at hensynet til personvernet skal veie tyngst dersom det blir konflikt mellom den registrerte og forskningens interesser. Personvernet kan slik sett innebære reelle begrensninger i forskernes frihet.

Forskere må forholde seg til en rekke lover som krever omfattende søknadsprosedyrer før et forskningsprosjekt kan settes i gang. Elektronisk sammenstilling av helseopplysninger som kan knyttes til en enkeltperson, krever for eksempel at det opprettes et register.

Helseregisterloven gjelder for forskning som omfattes av de formål som er angitt. Et av formålene med loven er å bidra til informasjon og kunnskap om befolkningens helseforhold, årsaker til nedsatt helse og utvikling av sykdom, for administrasjon, kvalitetssikring, planlegging og styring gjennom forskning og statistikk (1).

Helseregisterloven gjelder for behandling av helseopplysninger $\mathrm{i}$ helsetjenesten og helseforvaltningen. Begrepet helsetjenesten og helseforvaltningen omfatter både de som driver med helseadministrasjon og de som er del av den utøvende helsetjenesten. Begrepet omfatter videre både privat og offentlig virksomhet. Dersom institusjonen, som forskningsprosjektet er tilknyttet, er en del av helseforvaltningen/helsetjenesten kommer helseregisterloven til anvendelse. Eksempler på dette vil være helseforetakene og Folkehelseinstituttet. Forskere ved universitet og høyskoler er enkeltaktører som vil kunne falle utenfor lovens virkeområde. De vil måtte forholde seg til tilsvarende bestemmelser i personopplysningsloven. Skillet vil ha liten praktisk betydning fordi bestemmelsene i helseregisterloven og personopplysningsloven stort sett er harmoniserte. Når innsamling av helseopplysningene i et forskningsprosjekt krever dispensasjon fra taushetsplikten, gjelder imidlertid reglene i helseregisterloven, uavhengig av om innsamlingen skjer i helsetjenesten eller helseforvaltningen (2).

Det er to forutsetninger som må ses i sammenheng før et helseregister anses som lovlig opprettet. For det første må det foreligge hjemmel for informasjonsinnhenting og for det andre må det foreligge hjemmel for opprettelse av registeret.

\section{INNHENTING AV HELSEOPPLYSNINGER TIL FORSKNING}

Den informasjon som ønskes innhentet i forskningsøyemed er ofte taushetsbelagt (3). Forskere må innhente samtykke fra den opplysningene omhandler, f.eks. pasienten, om ikke annet følger av lov (4). Samtykke skal være en frivillig, utrykkelig og informert erklæring fra den registrerte. Sosial- og helsedirektoratet 
anbefaler at det gis et skriftlig samtykke. Krav om samtykke gjelder ikke dersom Sosial- og helsedirektoratet beslutter at helseopplysninger kan brukes til forskning ved å gi dispensasjon fra taushetsplikten (5). Et annet eksempel på at det $\mathrm{i}$ lov er gitt adgang til å innhente opplysninger er helseregisterloven $\S \S 7$ og 8 . Disse reglene åpner blant annet for innsamling av opplysninger til bestemte kvalitetsregistre og andre epidemiologiske registre.

\section{ETABLERING AV HELSEREGISTER TIL BRUK I FORSKNING}

Helseregistre kan opprettes enten ved at det gis konsesjon fra Datatilsynet eller ved at det i forskrift eller lov gis tillatelse til å opprette et helseregister.

Flere helseregistre opprettes i dag ved konsesjon fra Datatilsynet (6). Dette forutsetter som hovedregel et samtykke fra den registrerte. Det kan også søkes om dispensasjon fra taushetsplikt til Sosial- og helsedirektoratet (7). Hvor det vil medføre store praktiske problemer enten å innhente samtykke eller å basere forskningen på anonyme opplysninger, vil Sosial- og helsedirektoratet vurdere om dispensasjon fra taushetsplikten skal gis. Lokale, regionale eller sentrale helseregistre kan opprettes av Kongen i statsråd ved forskrift (8). Eksempler på slike registre kan være epidemiologiske registre, sykdomsregistre og kvalitetsregistre som ikke har behandling av enkeltindivider som sitt primære formål. Dette forutsetter at den registrerte aktivt gir sitt samtykke eller at navn, fødselsnummer eller andre direkte identifiserende kjennetegn pseudonymiseres eller avidentifiseres.

Det første sentrale helseregister som er opprettet med pseudonyme helseopplysninger er "Reseptbasert legemiddelregister" som fikk sin forskrift i oktober 2003. Dette gjelder helseopplysninger der opplysning om identitet, dvs. navn, fødselsnummer og andre direkte personidentifiserende opplysninger er kryptert eller skjult, men likevel individualisert slik at det lar seg gjøre å følge hver person gjennom helsesystemet uten at identiteten røpes.

Avidentifiserte helseopplysninger er helseopplysninger der navn, fødselsnummer og andre personentydige kjennetegn er fjernet, slik at opplysningene ikke kan knyttes til en enkelt person og hvor identiteten bare kan tilbakeføres ved sammenstilling med de samme opplysninger som tidligere ble fjernet. Det er mulig å finne tilbake til hvem opplysningene gjelder ved hjelp av en kode. Pseudonyme helseopplysninger er en type avidentifiserte opplysninger.

Navn, fødselsnummer og andre direkte personidentifiserende kjennetegn kan behandles uten samtykke fra den registrerte når det etableres helseregistre ved lov. I dag er følgende registre opprettet ved lov: Dødsårsaksregisteret, Kreftregisteret, Medisinsk fødselsregister, Meldesystemet for infeksjonssykdommer, Det sentrale tuberkuloseregisteret og System for vaksinasjonskontroll (SYSVAK).
Regionale helseregistre er helseregistre som de regionale helseforetakene etablerer for å ivareta de oppgaver foretakene har, som for eksempel å sørge for at det tilbys spesialisthelsetjenester. Lokale helseregistre er helseregistre som den enkelte kommune etablerer for å ivareta de oppgaver kommunen har knyttet til helsetjenesten, som for eksempel å fremme helse og forebygge sykdom. Per dags dato er det ikke etablert lokale eller regionale helseregistre av Kongen i statsråd ved forskrift. Sentrale helseregistre er helseregistre som den sentrale helseforvaltningen etablerer for å ivareta landsomfattende oppgaver/landsfunksjoner.

Det kan reises spørsmål om hvilke helseregistre som bør opprettes ved forskrift og hvilke helseregistre Datatilsynet kan gi konsesjon til. Helsedepartementet har lagt til grunn at sykdomsregistre og kvalitetsregistre som omfatter flere diagnosetyper over hele befolkningen, bør reguleres i forskrift av Kongen i statsråd. Det samme gjelder sykdomsregistre, kvalitetsregistre eller helseregistre som inneholder svært følsomme opplysinger. Mindre omfattende registre som ikke inneholder spesielt sensitiv informasjon bør kunne opprettes etter konsesjon fra Datatilsynet. Dette bør også gjelde forskningsrelaterte registre av begrenset varighet.

Da helseregisterloven ble behandlet i Stortinget var Sosialkomiteen opptatt av at man bør være tilbakeholdne med å opprette registre som omfatter hele befolkningens livsførsel. Disse bør være avidentifisert eller pseudonymisert. Datatilsynet har lagt seg på en streng linje når det gjelder å gi konsesjon.

\section{HVA SKAL TIL FOR AT DATA FRA DE SENTRA- LE REGISTRENE SOM ER OPPRETTET VED LOV KAN GJØRES TILGJENGELIG?}

Enhver som behandler helseopplysninger etter helseregisterloven har taushetsplikt både etter helsepersonelloven og forvaltningsloven (9). Forskriftene til Dødsårsaksregisteret, Kreftregisteret, Medisinsk fødselsregister, SYSVAK-register, Meldesystemet for infeksjonssykdommer og Det sentrale tuberkuloseregisteret har bestemmelser om sammenstilling og utlevering av helseopplysninger (10). I fortsettelsen vises det til Medisinsk fødselsregisterforskriften (11). Tilsvarende bestemmelser følger av de andre registerforskriftene.

\section{Fremstilling av statistikk}

Opplysninger i Medisinsk fødselsregister kan sammenstilles med opplysninger i Dødsårsaksregisteret, Kreftregisteret, Meldesystemet for infeksjonssykdommer, Det sentrale tuberkuloseregisteret og SYSVAKregisteret for utarbeidelse av statistikk dersom resultatet av sammenstillingen fremkommer $\mathrm{i}$ anonymisert form (12). Statistikkframstilling kan gjøres av den databehandlingsansvarlige for ett av de nevnte registrene eller virksomhet som departementet har godkjent 
for slikt formål. Det vil ikke være nødvendig å innhente samtykke fra den registrerte eller søke direktoratet om dispensasjon fra taushetsplikt.

\section{Forskning på sammenstilte helseopplysninger}

Nasjonalt folkehelseinstitutt kan sammenstille opplysninger i Medisinsk fødselsregister med opplysninger i Dødsårsaksregisteret, Kreftregisteret, Meldesystemet for infeksjonssykdommer, Det sentrale tuberkuloseregisteret og SYSVAK-registeret til bruk for forskning internt i Medisinsk fødselsregister (13).

Det er tre vilkår som må være oppfylt for at ovennevnte sammenstilling skal kunne skje:

1) Prosjektet må ha et uttrykkelig angitt formål innenfor det aktuelle registerets formål (14);

2) Forskeren skal bare behandle avidentifiserte data;

3) Behandlingen av opplysningene skal være ubetenkelig ut fra etiske hensyn.

Eksterne forskere, og andre som har oppgaver innen helsetjenesten/helseforvaltningen kan etter søknad til den databehandlingsansvarlige for det aktuelle register gis adgang til sammenstilte og tilrettelagte avidentifiserte data fra Dødsårsaksregisteret, Medisinsk fødselsregister, Kreftregisteret, Meldesystemet for infeksjonssykdommer, Det sentrale tuberkuloseregisteret og SYSVAK-registeret til bruk for forskning (15). Det forutsettes at dataene skal brukes innenfor angitt formål i forskriften (14).

Utlevering av avidentifiserte data til forskere anses ikke å være i strid med helsepersonellovens eller forvaltningslovens bestemmelser om taushetsplikt. Opplysningene er ikke anonyme, da sammenstillingsog tilretteleggingsinstansen vil kunne tilbakeføre opplysningene. Derimot skal mottaker ikke være i stand til å tilbakeføre opplysningene, og de vil derfor fremstå som anonyme for forskeren. Det vil derfor ikke være behov for samtykke fra den registrerte eller vedtak om dispensasjon fra taushetsplikten (16).

Utlevering av opplysninger fra Medisinsk fødselsregister for sammenstilling med forskerens egne data krever som hovedregel konsesjon fra Datatilsynet og må være i samsvar med reglene om taushetsplikt (17). Her må det som hovedregel foreligge et vedtak om dispensasjon fra taushetsplikten. Et eksempel på dette vil være en forsker som ønsker å koble data fra Medisinsk fødselsregister med egne opplysninger fra egne helseundersøkelser, biologisk materiale eller journalopplysninger.

\section{ANDRE FORHOLD}

En av de regionale etiske komiteenes oppgaver er å gi råd og veiledning etter en alminnelig forskningsetisk vurdering, hvor det også tas hensyn til forskningsetiske retningslinjer av nasjonale og internasjonale organer (f.eks. Helsinkideklarasjonen). Komiteene skal blant annet forelegges samtlige biomedisinske forskningsprosjekter hvor det inngår forsøk på mennesker og som ikke er av en slik art at det regnes som en del av vanlig etablert behandlingsprosedyre (18).

Det er en forutsetning at lovverket skal ivareta både hensynet til individet og hensynet til samfunnet $\mathrm{i}$ forbindelse med forskning. Regelverkets intensjon er å få til en riktig balansegang mellom disse. Det er opprettet et utvalg for vurdering av spørsmål vedrørende regulering av medisinsk forskning (Forskningsreguleringsutvalget eller Nylennautvalget) (19). Utvalgets arbeid vil munne ut i en innstilling innen 1. desember 2004. En viktig oppgave for utvalget vil være å vurdere hva som kan gjøres for å sikre en hensiktsmessig og klar regulering av medisinsk forskning, bl.a. med sikte på å ivareta forsøkpersoners rettigheter og verne om den personlige integritet.

\section{REFERANSER}

1. Lovene som det refereres til finnes på www.lovdata.no, herunder lov 18. mai nr. 242001 om helseregistre og behandling av helseopplysninger (helseregisterloven) $\S 1$, som trådte i kraft 1. januar 2002.

2. Ot. Prp. nr. 5 1999-2000 om lov om helseregistre og behandling av helseopplysninger s. 183.

3. Lov 2. juli 1999 nr. 64 om helsepersonell m.v. (helsepersonelloven) $\S 21$, helseregisterloven $\S 15$ og lov 10 . februar 1967 om behandlingsmåten i forvaltningssaker $\S \S 13$ til $13 \mathrm{e}$.

4. Helseregisterloven $\S 5$ tredje ledd.

5. Helsepersonelloven $\S 29$ og forvaltningsloven $\S 13 \mathrm{~d}$.

6. Helseregisterloven $\S 5$, jf. personopplysningsloven $\S \S 9$ og 33. Skjema for søknad om konsesjon for behandling av personopplysninger finnes på www.datatilsynet.no.

7. Skjema for søknad om dispensasjon fra taushetsplikt finnes på www.shdir.no under tjenester og skjema.

8. Helseregisterloven $\S \S 7$ og 8 .

9. Helseregisterloven $\S 15$.

10. Helseregisterloven $\S \S 8$ fjerde ledd, 14 og 12 .

11. Forskrift om innsamling og behandling av helseopplysninger i Medisinsk fødselsregister av 21. desember 2001 nr. 1483 (Medisinsk fødselsregisterforskriften).

12. Medisinsk fødselsregisterforskriften $\S 3-1$ 
13. Medisinsk fødselsregisterforskriften $\S 3-2$.

14. Medisinsk fødselsregisterforskriften $\S 1-3$.

15. Medisinsk fødselsregisterforskriften $\S 3-3$.

16. Helsepersonelloven $\S \S 21,22$ og 29 og forvaltningsloven $\S 13 \mathrm{~d}$.

17. Medisinsk fødselsregisterforskriften $§ 3-5$.

18. www.etikkom.no/REK/

19. www.forskningsregulering.dep.no 